\title{
INNOVATIVE MECHANISMS OF REGULATION OF INTERREGIONAL SOCIO-ECONOMIC ASYMMETRY IN UKRAINE
}

\section{Nadiya Danko-Yutish}

Private institution of higher education "Bukovina University", Chernivtsi, Ukraine

(C) MESTE NGO

JEL Classification: 018, R11, R12

\begin{abstract}
In the article there are analyzed the need for development and implementation of innovation-oriented regional development policy, and development of new innovative instruments of regional development that would be effective in terms of Ukraine's transition to a market economic system, as well as the essence of innovation potential and its place in the structure of the social and economic potential. The article shows the number of scientific theories that explain the dynamics of regional development and, consequently, causes asymmetries that are formed between regions. Here are also analyzed more innovative theories of regional development, the list of specific mechanisms for innovative regional policy, and especially their impact on overcoming inter-regional socio-economic asymmetry in Ukraine.
\end{abstract}

Keywords: socio-economic asymmetry, innovative potential, innovative model of regional development, regional innovation systems, clusters, "learning region", innovative growth poles, venture capital investments, Spin-off Company

\section{INTRODUCTION}

Defined strategy of modernization of the Ukrainian economy gradual transition to an innovative model of development initiates solving the problem of providing stable and long-term dynamics of social and economic processes at

Address of the author:

Danko-Yutish Nadiya

跮- Dankon@ukr.net the regional level. The process of transformation of the Ukrainian economy, and especially its expression in terms of the spatial organization of the economy of the specific regions determine different directions of mechanisms of influence, which is found to strengthen the social and economic disparities within a single domestic space. Traditional management of socioeconomic development of regions under harsh structural changes, caused by the transition to a market economic system and increased competition for resources of innovative 
development, show to be ineffective and cause the need to improve existing mechanisms for regional growth, the development of new innovative instruments, especially those that are linked on to the provision of converged model of development in Ukraine.

In this context there is a need for scientific justification of methodological approaches to the formation of institutional conditions to ensure a balanced development of the region's economy by adapting its business to an innovative model of development.

\section{MODELS OF REGIONAL DEVELOPMENT - INNOVATIVE POTENTIAL OF thE REGION}

In economics identified two most common models of regional development - traditional (in which the economic growth of the region based on the intensity and effectiveness of such traditional factors as land, labor, capital and entrepreneurial activity) and innovative (according to which the dynamics of the region depends on its ability to successfully use such objective factors as innovation, time and space). If traditional factors designed to meet the constant, implicit, unchanging needs, objective factors relate to the new, acquired, non-permanent, inexhaustible needs.

The advantages of such an innovative regional economic development, based on objective factors of production that are associated with the base, the epoch-making innovations, Russian scientist A.V. Herasymov includes:

- The ability to meet old needs in new ways, as an innovative product or service solves the old problem of the new method (based on innovation capacity is improving innovation);

- The ability to meet new needs in new ways when innovation fundamentally solves the new problems of social and economic development of the region and is the result of the reorientation of the regional economy for the challenges of higher economic structure (the basis of the innovative capacity forms basic innovations);

- The ability to create new needs and satisfy them. This innovation acts not only as the root cause of the emergence of new demand and new markets, niche markets, industries of various economic sectors, occupations, jobs, etc., but also as a powerful factor in the transition to a higher quality of social and economic functioning of the region (based on innovation capacity is epochal innovation) (Gerasimov, 2011a) (Gerasimov, 2011b).

The results of the study of scientific principles and international experience show critical objective factors in the innovative development of territories as well as their relationship to traditional factors of reproduction. Traditional factors of reproduction of regional economy are considered as relict and superior technical elements of the traditional way (industrial). The basis of the new, which is based on education and information economy, is objective factors such as innovation.

The development of regional economy through innovation growth potential is characterized by a concentration of intellectual resources, the increasing role of information, logistics and environmental factors. The factors of time, space and resources as innovation and competitiveness attribute begin to dominate in the creation of added value, obtaining the maximum rent from mass production and implementation of new technologies, products and services.

With meta-factors for regional economic development linked "innovative capacity", which is a manifestation at the regional level capacity for implementation of innovation, which in its turn is reflected in the various regional development strategies, activities, plans and concrete steps to implement them. In other words this is an ability of the regional socio-economic system to accumulate and effectively implement innovative potential.

Among the main characteristics of the observed increase innovation potential creation of bifurcation points (development) - the state of the critical points of regional socio-economic systems, creating preconditions for the transition to a qualitatively new level of social and economic progress of the regions and territories.

Thus, the innovation potential of the region cannot be considered as one of its components of the socio-economic along with natural- resource, 
human, industrial, organizational, informational, geospatial and etc. potential. After an innovative model of regional development is the ability to create and implement innovative tools, products, approaches in each of these segments, which proves its inequivalent other structural elements of the region's potential. A place of innovation potential in the structure of social and economic potential of the region is presented in Figure 1.

Generalized innovative potential of regional socio-economic system can be represented as follows:

$$
\operatorname{Ir}(t)=\left\langle K_{i}(t), I_{j}(t), P_{l}(t), U s(t), E_{f}(t)\right\rangle
$$

where:

$\operatorname{Ir}(t)$ - innovative potential of the region;

$K_{i}(t)$ - scientific potential th species;

$I_{j}(t)$ - intellectual and informational potential $j^{\text {th }}$ species;

$P_{l}(t)$ - industrial and technological potential of $\mathrm{I}-$ th species;

$U_{s}(t)$ - organizational and management capacity $s$ - species;

$E_{f}(t)$ - investment and financial capacity $f^{\text {h }}$ species;

$t$ - time.

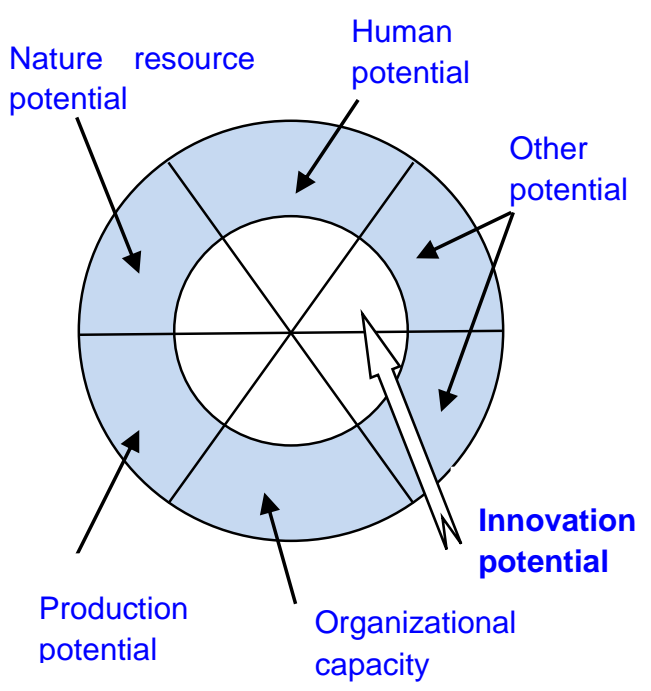

Fig. 1 Place of innovation potential in the structure of social and economic potential of the region (within innovative models of development)
Objective characteristics and its potential regional socio-economic system in this case are the limiting factor according to its innovative capacity. In addition, they determine the speed and intensity of innovative changes in the region, which always occur with a time lag.

The study of the major theoretical and conceptual foundations of regional development allows to talk about the need for building and implementing innovative potential of Ukraine's regions as the only possible direction of development and achievement of competitive position both within the national economic space, as well as in foreign markets. It should be noted that this argument applies to the economically strong regions with relatively high levels of development, and backward and depressed regions.

\section{THEORIES THAT EXPLAIN THE DYNAMICS OF REGIONAL DEVELOPMENT}

Let us consider the main factors for social and economic growth of regions in historical perspective. Among all the theories that explain the dynamics of regional development and, consequently, causes of asymmetries that are formed between regions can be divided into three areas:

1. Block of theories explaining export specialization and distribution of productive forces (16-20 century) (Luk'yanenko, Poruchnik, \& Stolyarchuk, 2008). These include the theory of international trade theory and location of economic regionalization. These theories are rather to study the principles and prerequisites of industrial specialization of regional economies. Of course, you must give credit to the authors of theories who understood and substantiated the reasons for the dynamics of the different regions based on the formation of the relative merits of economic actors and tied them to the terms of localization. But these theories, firstly, are considering only regions in terms of the components of the state's economy, not as independent economic actors, and secondly, do not justify the sources and factors of competitive 
advantages in the knowledge-based regional economy, where growth is through innovation.

2. Block of theories explaining the presence of the competitive advantages of the region (the end of 19 -20.). Prior to this unit the theories are including based on the concept of "new regionalism" of $\mathrm{M}$. Kiting: the theory of "flexible specialization" of M. Piore and Ch. Sabel (Piore, 1984), the theory of cumulative competitiveness of McCombie and Setterfield (Setterfield, 2002) (Shiltsin, 2013), the theory of endogenous growth by $R$. Martin and $P$. Sunley (1996). These authors consider national regions as separate economic entities in the international arena and focus on the existence of local competitive advantages. Also, these theories emphasize the role of information growth factor for regional development, and innovations are considered as a tool for improving productivity and accelerating growth of the gross regional product.

3. Block of innovative theories of regional development (mid 20-early 21 c.). The basis of the theory of this unit is an understanding that at the present stage of development of the world economy only through long-term increase of the rate of development of the regional economy can be achieved only through innovations that are considered as a constant process of creation of new knowledge and its implementation in practice. Given the purpose of our research will focus on reviewing these theories in detail.

One of the first theories of innovation orientation of regional development theory became Hegherstrand's "diffusion of innovation" (Pilipenko, 2005). The author showed that the presence of regional asymmetries in a market economy is an immanent phenomenon, since technological progress is spontaneous circulation.

The idea of uneven regional development was developed by F. Perry in the theory of "growth poles" (Perroux, 1995), who argued that innovations are concentrated around key areas that further produces a multiplier effect and forms a pole of growth, and Jane Jacobs (Henderson, 2001), who introduced into scientific circulation the concept of "region-city" - the local metropolitan area, serving the business hub of economic activity and becomes an arena for regional prosperity.

Since mid-1970s twenty Swiss schools formed their own territorial concentration (under the direction of $\mathrm{D}$. Maya), within which was the concept of "innovation environment", which was interpreted as a group of economic agents who where are able to perceive changes in globalization and encourage the development of localized territorial production system through innovation. In this theory innovation environment is seen as the locomotive of endogenous development. The authors identified five attributes of innovation environment (Maillat, 1998) (Maillat \& Grosjean, Globalization and territorial production systems, 1999):

- Spatial unity - geographic space without clear boundaries, but which has a certain unity, manifested through the behaviour of its subjects;

- Players of environment - firms, academic and educational institutions, the territorial government, the public;

- Specific elements as physical (infrastructure) and intangible (know-how, rules of interaction between players);

- Logic of organization, the ability to cooperate with each other efficiently using resources;

- The ability of players to improve themselves.

In the late 20th century considerable attention was paid to scientific study of the mechanism of operation and advantages of the cluster theory of regional development. Its founder, Professor Porter treats the cluster as a group of geographically close of interconnected companies and related organizations that are characterized by common activities and complementarity (Sokolenko, 2004). Establishing networks and technological innovation in the concentration of sources within the cluster can significantly enhance innovation in the territory where it resides. 
The most common method of providing financial development and implementation of innovations in production within clusters were venture capital funds. For example, in the USA more than half of biotech innovators organizations are funded by venture capital funds.

The importance of establishing effective innovation systems at the regional level was proved in the theories of creative regions and regional innovation systems (Asheim, Isaksen, Nauwelaers, \& Todtling, 2003) (Asheim \& Gertler, Understanding regional innovation systems, 2004). The authors linked the dynamics of regional development with an established presence in the region of interaction between institutions of education, science, business and other actors of the innovation process and offered "innovative model of interaction." The researchers emphasize the importance of adequate infrastructure accumulation and diffusion of innovation and reducing communication channels in the transmission of knowledge to direct contacts.

Thus, the innovative theories of regional development consider regions not only as independent economic agents, but also as epicenters of the creation and accumulation of new knowledge, allowing regional economic systems to gain a competitive status in the long run.

Considered scientific principles of innovationoriented regional development suggest the need for development and implementation of innovation-oriented regional development policy that would provide conditions for the implementation capacity of areas to intensify innovative activities in an integrated and efficient use of resource potential. The essence of innovation-oriented management to achieve the harmonious development of the region is to build a set of control actions based on the use of new methods (including program- target method, a synergistic approach, fuzzy modeling methods, etc.), financial and institutional mechanisms towards ensuring rational proportions reproductive (territorial sectoral and intersectoral, investment, resource support, etc. ) in their economic, industrial, social and other spheres, as well as creating conditions for economic modernization and development of innovative activities.

Formation and implementation of specific areas of governance arrangements should be based on principles that provide institutional conditions for reconciling the interests and objectives of all actors of the regional economy, their access to sources of innovative growth, expanding the authority and responsibility of regional authorities in the field of harmonious development of the territory (including through its resource support ) that define the role and place of local entities in implementing the strategy of innovation -oriented regional development. In this regard, an important methodological point is to complement existing principles of regional development as follows:

- Compliance with the proportionality of the key sectors and segments of the economy at the regional and national levels, and as a result reduction of intra-and interregional structural asymmetries;

- Ensuring the growth of economic potential through integration and more efficient sharing of internal competitive resources through increased interaction entities (local, regional, national and global corporations);

- Targeted regulation in order to achieve reproduction proportions of resource flows in the system of public financing, as well as regional markets for goods, services and investments.

\section{BASIC INNOVATIVE MECHANISMS OF REGULATION OF INTERREGIONAL SOCIO-ECONOMIC ASYMMETRY}

The basic mechanisms of management of innovative development regions are:

1. The formation and development of regional innovation systems (RIS). RIS - is a specific economic system that combines territorial government bodies, business and innovation infrastructure designed to enhance innovation in the region in accordance with the strategy of innovative development of the region and the main directions of innovation policy. The main purpose of creating the RIS is to provide conditions to improve the economic development of the region through effective use of its intellectual capacity, 
generation, dissemination and implementation of new knowledge.

Thus, the RIS is an organizational- economic mechanism and the social institution of postindustrial economy, which directs research and development to improve the competitiveness of the economy and social sphere of the region, and companies and organizations - the widespread use of scientific, technical, and organizational development for the production of high quality and innovation. This system is an integral component of the national innovation system and is based on a combination of market competition with the active use of instruments of regional economic and social policies.

2. Support existing and activation of new clusters of regional and interregional type. The positive effects of cluster formation is the development of cooperation and partnership between companies, in turn, stimulates the generation of innovation, accelerating the spread of information, activates interactive learning process, reduces transaction costs and thus creates a competitive advantage for the members of the cluster.

3. More efficient use of the creative potential of the region. The development of the region on the basis of innovation depends on the ability of the region to accumulate and effectively use the creative potential of the population, respectively, requires the implementation of policies at the national and regional levels, which would be popularized and encouraged people to create, receive and absorb knowledge. A prerequisite for this is the implementation in practice of the concept of "lifelong learning".

Some regions are making great progress in this direction. For their characteristics scientists use the concept of «learning region» and underline the key role of knowledge creation and collaborative learning in providing innovation and economic growth in the region.

4. Establishing inter-relationships and interregional integration. Interregional cooperation is one of the most effective mechanisms for activation of innovative processes and investment to implement reliable, innovative projects that can create new centers of economic development, which can be formed around areas of growth opportunities through consolidation of resources and efforts in the implementation of regional projects of common interest.

5. Formation innovation growth poles in cities with high scientific potential. A special role in the innovative development of the regions play major cities, which are centers of knowledge management. This is due to the influence of factors such as the concentration of headquarters of major companies and headquarters of multinationals, which promotes the development of business infrastructure and expansion the range of business services, the concentration of a significant number of qualified researchers and developers, contributing to the establishment of close contacts within the city, the presence of more developed significantly higher (compared to other areas) information and communication and transport infrastructure, the concentration of people (especially young people) with entrepreneurial talent in which there are more opportunities to implement within the city. Thus, the action of agglomerating effect occurs.

6. Formation of a favorable business environment and increase of the investment attractiveness of regions (particularly for venture investments). Foreign direct investments have a direct impact on the pace of innovation development as involving the transfer in the region of innovative technologies, products, and much higher quality standards, innovative approaches to the management of enterprises, social groups and regions. In addition, the arrival into a region of a number of powerful companies promotes cluster initiatives.

Significant role in providing innovative investment of just playing venture investments are inherently risky to finance innovative projects, and thus serve as the commercialization of innovation. The 
presence of regional venture funds directly determines the probability and speed of introduction of an innovative product.

7. Intensification of regional information and communication infrastructure. The importance of having in a region highly developed IT infrastructure is due to its function within the regional innovation system: the repeater, distributors of new knowledge and information. The importance of this factor has increased especially in view of the information society, which requires the ability of each participant to build interactive innovation processes, interaction and direct contacts in real time.

8. Activation of internal labor migration. Regional innovation policy could also encourage mobility of labor, as it is an effective way to transfer skills and knowledge from one local company to another. Another key measure is to encourage the immigration of skilled labor as it brings new ideas and expertise to the region. This can be achieved, for example, through international exchange programs for students, both for those who come to study in the region and those who leave, but will return with new knowledge and experience.

9. Promote the creation of Spin-off companies. Government policies can also promote effective transfer of knowledge through the creation of spin-off companies. Spin-off company - a company that is established by entrepreneurs who previously worked in the company of the same or related sectors. Spin-off companies often find themselves successful because based on the accumulated knowledge of their owners. They are usually located near the "parent" company and can be seen as a mechanism to ensure regional economic diversity in new sectors, as based on the knowledge and skills available in existing sectors.

The effectiveness of innovative mechanisms marked growth dynamics of regional development is directly determined by the adaptation capacity of the region. It is about the ability of the regional companies, industries and institutions feel the change (market, technological, organizational) to learn, adapt and update their knowledge and expertise, and to develop and improve organizational skills, which together enables the conversion of new knowledge into effective action. The higher the adaptive capacity of innovation of regional economy and social institutional base is, the better the region provides and implements its competitive advantage.

\section{CONCLUSIONS}

Summarizing these researches of scientific principles for implementation of innovative instruments of regional development should be noted that regional economic development is uniquely determined by the previous retrospective development, that is, hereditary. This suggests that the ability (capacity) to produce the region actively and effectively implement innovations to accelerate the pace of economic development depends on the structure of the economy, the available technology, development of institutional structures, etc. in the region. However, the trajectory of the future economic development of the region is not determined by mechanically previous trajectory. Constantly changing market and competitive conditions, combined with innovative processes, creating new "windows of opportunity" and, hence, potentially new path of regional economic dynamics, as there are new companies, new technologies, products and skills.

There are numerous examples of regions that have managed to turn relative economic decline by restructuring their economies and the use of innovative mechanisms. This restructuring involves a substantial reallocation of resources between sectors, technologies and skills and is fully determined by market demands. But usually it also requires a change in the regional institutional forms and norms of behavior, as they form the innovation and the way in which markets relay changes. The role is potentially weighed and comprehensive regional policy. 


\section{Works Cited}

Asheim, B., \& Gertler, M. (2004). Understanding regional innovation systems. In J. Fagerberg, D. Mowery, \& R. Nelson, The Oxford Handbook of Innovation. Oxford: Oxford University Press.

Asheim, B., Isaksen, A., Nauwelaers, C., \& Todtling, F. (2003). Regional Innovation Policy for SmallMedium Enterprises. Edward Elgar Publishing.

Gerasimov, A. (2011a). Vzaimosvyaz' urovnya innovatsionnoy aktivnosti i konkurentosposobnosti regional'noy ekonomiki. Finansovaya ekonomika(3-4), 107-110.

Gerasimov, A. (2011b). K voprosu o formirovanii innovatsionnogo potentsiala regiona. Ekonomika. Nalogi. Pravo(6).

Henderson, D. R. (2001, October 12). What the Nobel Economists Missed. Wall Street Journal. Retrieved from http://online.wsj.com/articles/SB1002844871126597040

Luk'yanenko, D. G., Poruchnik, A. M., \& Stolyarchuk, Y. M. (2008). Globalna ekonomlka XXI st.: lyudskiy vimir. Kiev: KNEU.

Maillat, D. (1998). From the industrial district to the innovative milieux: contribution to an analysis of territorialized productive organizations. Working Paper 9606b, 28. University de Neuchetel. Retrieved 08 25, 2014, from http://econpapers.repec.org/paper/ctllouvre/1998017.htm

Maillat, D., \& Grosjean, N. (1999). Globalization and territorial production systems. In D. Maillat, \& N. Grosjean, Innovation, Networks and Localities (pp. 50-65). Springer Berlin Heidelberg. doi:10.1007/978-3-642-58524-1_4

Martin, R., \& Sunley, P. (1996). Slow convergence? Post-neoclassical Endogenous Growth Theory and Regional Development. Working Paper 44. Cambridge: ERSC Center for Business Research. University of Cambridge.

Perroux, F. (1995). Economic space: theory and applications. Quarterly Journal of Economics, 64, 89104.

Pilipenko, I. V. (2005). Konkurentosposobnost stran i regionov $v$ mirovom hozyaystve: teoriya i opyit malyih stran. Smolensk: Oykumena.

Piore, M. S. (1984). The second Industrial Divide: Possibilities for Prosperity. New York: Basic Books.

Setterfield, M. (2002). A model of Kaldorian traverse: cumulative causation, structural change and evolutionary hysteresis. In M. Setterfield, The Economics of Demand-Led Growth (p. 320). Edward Elgar Publishing. doi:10.4337/9781843765325

Shiltsin, Y. A. (2013). Voprosy otsenki regional'noy asimmetrii (na primere Rossii). In V. Y. Seliverstov (Ed.), Aktual'nyye problemy sotsial'no-ekonomicheskogo razvitiya: vzglyad uchonykh: sb. nauchnykh trudov (pp. 143-158). Novosibirsk: IEOPP SO RAN. Retrieved from http://econom.nsc.ru/ieie/smu/conference/articles/ШильцинE.doc

Sokolenko, S. I. (2004). Klasteri v globalniy ekonomitsi. Kiev: Logos.

Received for publication:

Revision received:

Accepted for publication:
31.03.2014

28.09.2014

14.10.2014 


\section{How to cite this article?}

Style - APA Sixth Edition:

Danko-Yutish, N. (2015, Jan 15). Innovative mechanisms of regulation of interregional socio-economic asymmetry in Ukraine. (Z. Čekerevac, Ed.) MEST Journal, 3(1), 95-103. doi:10.12709/mest.03.03.01.11

Style - Chicago Fifteenth Edition:

Danko-Yutish, Nadiya. 2015. "Innovative mechanisms of regulation of interregional socio-economic asymmetry in Ukraine." Edited by Zoran Čekerevac. MEST Journal (MESTE) 3 (1): 95-103. doi:10.12709/mest.03.03.01.11.

Style - GOST Name Sort:

Danko-Yutish Nadiya Innovative mechanisms of regulation of interregional socio-economic asymmetry in Ukraine [Journal] // MEST Journal / ed. Čekerevac Zoran. - Belgrade : MESTE, Jan 15, 2015. - 1 : Vol. 3. - pp. 95-103.

Style - Harvard Anglia:

Danko-Yutish, N., 2015. Innovative mechanisms of regulation of interregional socio-economic asymmetry in Ukraine. MEST Journal, 15 Jan, 3(1), pp. 95-103.

Style - ISO 690 Numerical Reference:

Innovative mechanisms of regulation of interregional socio-economic asymmetry in Ukraine. DankoYutish, Nadiya. [ed.] Zoran Čekerevac. 1, Belgrade : MESTE, Jan 15, 2015, MEST Journal, Vol. 3, pp. 95-103. 